DOI https://doi.org/10.30525/978-9934-26-073-5-2-26

\title{
SEMANTIC TENSION AS A TOOL OF IMPACT: A TRANSLATIONAL ASPECT
}

\author{
Izotova N. P. \\ Doctor of Science, Associate Professor, \\ Professor at the Professor O. M. Morokhovsky Department \\ of English Philology, Translation, and Philosophy of Language, \\ Kyiv National Linguistic University \\ Kyiv, Ukraine
}

This study set out to explore translation strategies for reproducing semantic tension in Russian and Ukrainian translations of John Maxwell Coetzee's novel Disgrace with special regard to the rhetorical value of such tension.

One of the essential features of Coetzee's Disgrace is the rise of structural and semantic tension [1, p. 14] which exposes the novelty of the author's meaning- and text-building strategies. Most prior research tended to focus on analyzing various means of creating tension in literary texts [5; 6]. The current paper discusses the issue of semantic tension in terms of its translatability in fiction. Therefore, the purpose of the present study is to ascertain the effectiveness of various translation strategies employed in Russian and Ukrainian versions of Coetzee's Disgrace to render semantic tension.

The plot of Disgrace revolves around the main character's psychoemotional response to a set of traumatic life events, such as his dismissal from the University after seducing his student; his daughter's raping by a group of black men; the farm-attack on David, etc. Accordingly, the accentuated psychologism runs through the whole novel and becomes conspicuous largely due to the rise of the semantic tension which, in turn, represents various forms of the character's psychoemotional tension, caused by certain traumatic event(s).

This paper argues that semantic tension in Disgrace arises from the density, hyperconcentration of textual meaning(s) as a result of the author's selection and combination of linguistic units with the purpose of creating the emphasized psychologism. Therefore, in this novel, semantic tension is signalled by various semantic deviations, caused by the author's idiosyncratic usage of emotive and expressive lexicon, syntactic patterns, and figurative language. 
Methodologically, the paper presents the analysis of semantic tension in terms of the «nodal points» technique [1, p. 13-15], which allows to focus on those lingual means that are significant for the rhetoric of semantic tension, both in the source and target texts.

The above-mentioned characteristics of semantic tension predetermine the analysis of translation strategies for reproducing this phenomenon in Disgrace's Russian and Ukrainian versions. It should be noted that a translation strategy is regarded as «a potentially conscious procedure» [8] for carrying out a particular translation task. Specifically, the translation strategy relates to the translator's choices which demonstrate his / her linguistic preferences [4].

Let us consider how the semantic tension is reproduced in Disgrace's translations into Russian and Ukrainian:

A flurry of anger runs through him, strong enough to take him by surprise. He picks up his spade and strikes whole strips of mud and weed from the dam-bottom, flinging them over his shoulder, over the wall. You are whipping yourself into a rage, he admonishes himself: Stop it! Yet at this moment he would like to take Petrus by the throat. [...] Violation: that is the word he would like to force out of Petrus. Yes, it was a violation, he would like to hear Petrus say; yes, it was an outrage [7, p. 119].

Гнев внезапно охватывает его, настолько сильный, что даже берет его врасплох. Он хватает лопату $и$, ударами сдирая со дна целые комья травы и грязи, через плечо мечет их за стенку пруда. «Ты сам себя взвинчиваешь, - предостерегает он себя. - Прекрати!»И все же в этот миг он с наслаждением вцепился бы Петрасу в глотку. [...] «Осквернение» - вот то слово, которое ему хотелось вытянуть из Петраса. «Да, это было осквернение, - хотел усльшать он, - да, это было насилие» [2, p. 106].

Його раптово накривас хвилею гніву, такою сильною, щчо він $і$ сам не сподівався. Він хапається за лопату $і$, здираючи з дна водосховища цілі смуги бруду й бур'янів, кидає їх через плече за стінку. «Ти сам накручуєшся, - умовляє він себе. - Припини!" Цієї миті йому хочеться схопити Петруса за горло. [...] «Насилля»-йому хочеться витягти з Петруса ие слово. "Так, це було насилля, - йому хочеться почути, як каже той: - Так, це було знущання» [3, p. 122].

Both in the original and translated fragments, semantic tension is brought about by the convergence of lexical units denoting psychic and physical exteriorization of emotions, as well as figurative language, and expressive syntax. Thus, the emotional lexicon is rendered by way of lexico-semantic 
equivalence (flurry / гнев / гнів; violation / осквернение / насилля; outrage / насилие / знущання), stylistic loss (Үои are whipping yourself into a rage / Tы сам себя взвинчиваешь / Ти сам накручуєшся), and stylistic gain (he would like to take Petrus by the throat / он с наслажсдением виепился бы Петрасу в глотку).

Action verbs, which indirectly point to David's psychoemotional tension, are rendered via lexico-semantic equivalence (He picks up his spade / Он хватает лопату / Він хапається за лопату; to take Petrus by the throat / он с наслаждением вцепился бы Петрасу в глотку / йому хочеться схопити Петруса за горло).

Grammar-related semantic loss, based on the substitution of the conditional mood by the indicative mood, occurs in the translation of the sentence he would like to hear Petrus say into Russian and Ukrainian (хотел усльшиать он / йому хочеться почути). Consequently, the idea of the character's uncertainty and distract becomes weaker.

Associative-figurative and functional equivalence in the translations is ensured by preserving the semantics and rhetoric of the verbal metaphor of high-intensity anger (A flurry of anger runs through him, strong enough to take him by surprise / Гнев внезапно охватывает его, настолько сильныи, что даже берет его врасплох / Його раптово накриває хвилею гніву, такою сильною, що він і сам не сподівався).

Syntactic equivalence in the Russian and Ukrainian translations of the original fragment reveals itself through retaining the same expressive syntactic patterns, including syntactic parallelism (it was a violation; it was an outrage / это было осквернение, это было насилие / це було насилля / це було знущання) and exclamatory sentence (Stop it! / Прекрати! / Припини!).

Thus, in Russian and Ukrainian translations of Disgrace semantic tension is reproduced through lexico-semantic, syntactic, and associative-figurative equivalence, loss and gain.

\section{References:}

1. Ізотова Н. П. Ігорова стилістика сучасного англомовного художнього наративу в лінгвістичному висвітленні (на матеріалі романів Дж.М. Кутзее): автореф. дис. ‥ доктора філол. наук: 10.02.04. Київ, 2019. 35 с.

2. Кутзее Дж. М. Бесчестье / Перев. с англ. С. Ильин. Москва: Изд-во Эксмо, 2010. $318 \mathrm{c.}$

3. Кутзее Дж. М. Безчестя / Перекл. 3 англ. Є. Даскал. Харків: Клуб сімейного дозвілля, 2017. 221 с. 
4. Радбиль Т. Б. Переводимость как феномен межъязыкового взаимодействия. Логический анализ языка. Перевод художественных текстов в разные эпохи. Москва: Индрик, 2012). С. 7-12.

5. Ретуева Л. М. Семантическая напряженность художественного прозаического произведения (на материале романов А. Мэрдок и М. Дрэббл): автореф. дис. ... канд. филол. наук: 10.02.04. Одесса, 1988. $16 \mathrm{c}$.

6. Шехтман Н. А. Семантическая напряженность текста и его понимание. Вестник Челябинского государственного педагогического университета. 2013. № 12. С. 166-173.

7. Coetzee J. M. Disgrace. London: Vintage, 2011. 220 p.

8. Lörscher, W. Translation Performance, Translation Process, and Translation Strategies. A Psycholinguistic Investigation. Gunter Narr, Tübingen, $1991.307 \mathrm{p}$.

DOI https://doi.org/10.30525/978-9934-26-073-5-2-27

\title{
МЕТОДИ ДОСЛІДЖЕННЯ БАГАТОЗНАЧНОСТІ
}

\author{
Кабаченко І. Л. \\ доиент кафедри перекладу \\ Національного технічного університету «Дніпровська політехніка» \\ м. Дніпро, Украӥна
}

Стрімкий розвиток науки і техніки, що спостерігається в Україні, як і у всьому світі, кожного дня спричиняе впровадження нових понять та термінів у різні сфери мови. Проте проблемою лишається те, що розуміти терміни стає дедалі важче. Ця проблема зумовлена по перш за все багатозначністю термінів. Тож оскільки саме багатозначність або полісемія $\epsilon$ основним компонентом, що призводить до нерозуміння значень слів людьми, іiі вивчення заслуговує особливе місце у мовознавстві.

Полісемія (грецьк. polysemos - багатозначний) - це наявність у мовної одиниці декількох значень. Лексична полісемія - це здатність одного слова означати різні предмети та явища дійсності. Для прикладу розглянемо два іменника. 